McGill Journal of Education

Revue des sciences de l'éducation de McGill

ENHANCING UNDERSTANDINGS OF EMERGING PHYSICAL EDUCATION PRACTICAL THEORY: ABORIGINAL TEACHER CANDIDATES’ REFLECTIVE JOURNALING PRACTICES AMÉLIORER LA COMPRÉHENSION DE LA THÉORIE PRATIQUE ÉMERGENTE DE L'ÉDUCATION PHYSIQUE : PRATIQUES DE RÉDACTION RÉFLÉCHIES DES ÉTUDIANTES ET ÉTUDIANTS AUTOCHTONES EN ENSEIGNEMENT

Joe Barrett, Lorenzo Cherubini et Dan Robinson

Volume 53, numéro 1, winter 2018

URI : https://id.erudit.org/iderudit/1056280ar

DOI : https://doi.org/10.7202/1056280ar

Aller au sommaire du numéro

\section{Éditeur(s)}

Faculty of Education, McGill University

ISSN

1916-0666 (numérique)

Découvrir la revue

Citer cet article

Barrett, J., Cherubini, L. \& Robinson, D. (2018). ENHANCING UNDERSTANDINGS OF EMERGING PHYSICAL EDUCATION PRACTICAL THEORY: ABORIGINAL TEACHER CANDIDATES' REFLECTIVE JOURNALING PRACTICES. McGill Journal of Education / Revue des sciences de l'éducation de McGill, 53(1), 11-25.

https://doi.org/10.7202/1056280ar
Résumé de l'article

Le présent document décrit les résultats d'une étude qui visait à explorer, en collaboration avec des étudiants autochtones en enseignement, la théorie pratique émergente de l'éducation physique (EP) à l'aide de pratiques de tenue d'un journal réflexif. La théorie pratique peut être décrite comme l'ensemble personnel et dynamique de valeurs, de connaissances et d'expériences d'une personne qui guide, en partie, les choix et les comportements pédagogiques. Dans l'analyse thématique des journaux de réflexion des étudiantes et étudiants en enseignement, on a pris soin d'honorer et de confirmer les voix de neuf étudiantes et étudiants autochtones. Quatre thèmes clés ont été identifiés : la marginalité (activités étrangères et attentes stéréotypées), la préservation de la culture par l'éducation physique, l'engagement des aînés dans l'éducation physique et le regard vers l'avenir. Les résultats peuvent servir à informer les personnes qui s'intéressent aux pratiques de réflexion dans la formation à l'éducation physique et à la formation à l'enseignement de l'éducation physique (FEEP) ou à la formation à l'enseignement des Autochtones.
All Rights Reserved @ Faculty of Education, McGill University, 2018
Ce document est protégé par la loi sur le droit d'auteur. L'utilisation des services d'Érudit (y compris la reproduction) est assujettie à sa politique d'utilisation que vous pouvez consulter en ligne.

https://apropos.erudit.org/fr/usagers/politique-dutilisation/ 


\title{
ENHANCING UNDERSTANDINGS OF EMERGING PHYSICAL EDUCATION PRACTICAL THEORY: ABORIGINAL TEACHER CANDIDATES' REFLECTIVE JOURNALING PRACTICES
}

JOE BARRETT \& LORENZO CHERUBINI Brock University

DAN ROBINSON St. Francis Xavier University

\begin{abstract}
This paper describes results from a study that arose to explore, alongside Aboriginal teacher candidates, emerging physical education (PE) practical theory utilizing reflective journaling practices. Practical theory can be described as an individual's personal and dynamic set of values, knowledge, and experience that guides, in part, teaching choices and behaviours. In the thematic analysis of teacher candidates' reflective journals, care was taken to honour and confirm the voices of nine Aboriginal teacher candidates. Four key themes were identified: marginality (foreign activities and stereotypical expectations), cultural preservation through PE, Elder involvement in PE, and looking to the future. The results may serve to inform those with an interest in reflective practices in physical education teacher education (PETE) and/or Aboriginal teacher education.
\end{abstract}

\section{AMÉLIORER LA COMPRÉHENSION DE LA THÉORIE PRATIQUE ÉMERGENTE DE L'ÉDUCATION PHYSIQUE : PRATIQUES DE RÉDACTION RÉFLÉCHIES DES ÉTUDIANTES ET ÉTUDIANTS AUTOCHTONES EN ENSEIGNEMENT}

RÉSUMÉ. Le présent document décrit les résultats d'une étude qui visait à explorer, en collaboration avec des étudiants autochtones en enseignement, la théorie pratique émergente de l'éducation physique (EP) à l'aide de pratiques de tenue d'un journal réflexif. La théorie pratique peut être décrite comme l'ensemble personnel et dynamique de valeurs, de connaissances et d'expériences d'une personne qui guide, en partie, les choix et les comportements pédagogiques. Dans l'analyse thématique des journaux de réflexion des étudiantes et étudiants en enseignement, on a pris soin d'honorer et de confirmer les voix de neuf étudiantes et étudiants autochtones. Quatre thèmes clés ont été identifiés : la marginalité (activités étrangères et attentes stéréotypées), la préservation de la culture par l'éducation physique, l'engagement des aînés dans l'éducation physique et le regard vers l'avenir. Les résultats peuvent servir à informer les personnes qui s'intéressent aux pratiques de réflexion dans la formation à l'éducation physique et à la formation à l'enseignement de l'éducation physique (FEEP) ou à la formation à l'enseignement des Autochtones. 
It stands to reason that teacher candidates' disposition and intent to teach a particular subject would be, in part, shaped by their own lived experiences as students in schools. Lortie (1975) has noted that teachers' past school experiences can have a significant impact on the attitudinal disposition and beliefs that they bring to preservice teacher education and into the classroom as practicing teachers. Further, curriculum theorists have hypothesized that teachers' value systems determine, in part, their goals for student learning and expectations (McNeil, 1996). With respect to physical education (PE) teaching, evidence has suggested that a teacher's own experience, values, and beliefs associated with PE can affect their perceptions of and intent to provide PE instruction (Morgan \& Hansen, 2008; Portman, 1996; Wilcox, 1987).

The purpose of this research study was to explore, alongside Aboriginal teacher candidates, emerging PE practical theory utilizing reflective journaling practices. Practical theory can be defined as "a person's private, integrated but ever-changing system of knowledge, experience, and values which is relevant to practice at any particular time" (Handal \& Lauvas, 1987, p. 9). Within the study, emphasis was directed toward honouring each individual's own private and personal journey through a PE teaching methods course utilizing reflective journaling practices. It was our hope that reflective journaling, over time, would offer Aboriginal teacher candidates a personal and intimate space to "delve deeper within themselves and discover something new or work with something old" (MacMillan, 2010, p. 6). Our interpretations of practical theory are also rooted in the work of Dorovolomo (2004), who noted that practical theories can be understood as:

the conceptual structures and visions that provide teachers with reasons for acting as they choose in order to be effective. They are propositions that undergird and guide teachers' appreciation, decisions, and actions. Such theories are crucial to the success of teaching because educational problems are practical problems. (pp. 14-15)

Helping teacher candidates make explicit understandings of the component aspects of their own practical theories is essential - to see and understand the intermingling of personal experiences, transmitted knowledge, and core values on their emerging PE pedagogy (Handal \& Lauvas, 1987; Zeichner \& Liston, 2014). Heeding the words of Dewey (1938), we are particularly mindful of the responsibility to help teacher candidates' explore core values - ones that can be directly attributed to personal student, paraprofessional, and teacher candidate experience. He noted, for example, the following:

The belief that all genuine education comes about through experience does not mean that all experiences are genuinely or equally educative. Experience and education cannot directly be equated to each other. For some experiences are miseducative. Any experience is miseducative that has the effect of arresting or distorting the growth of further experience. (Dewey, 1938, p. 25) 
Considering teacher candidates' own personal experiences, values, and components of practical theory, physical education teacher education (PETE) faculty have a moral obligation to know "their students in the context of the students' historical identities" (Champagne, 2006, p. 16). Evidence has suggested that PETE faculty must understand and challenge teacher candidates' personal biographies if they are to be successful in altering beliefs regarding PE (Matanin \& Collier, 2003). Further, the quality of an individual's personal school-based PE experience can serve as a predictor of teachers' and teacher candidates' attitudes and beliefs about PE, as well as their commitment to physical activity (Morgan, Bourke, \& Thompson, 2001). If teacher educators fail to address the beliefs and values of teacher candidates, a rejection of the messages and lessons from teacher education could occur (Placek et al., 1995).

The relationship that exists between teacher candidates' PE practical theories and intent to teach PE, in part, provided the impetus for exploration through reflective journaling practices, understood as "a method of promoting exploration and facilitating reflection on learning" (Gillis, 2001, p. 49). PETE faculty and teacher candidates, together, endeavoured to utilize the act of reflective journaling as a method to uncover equally rich and complex personal PE stories, experiences, and values - core aspects to emerging PE practical theories rooted in their contextualized historical identities. The act itself was situated within a PE teaching methods course, providing safe time and place for prospective teachers to express / share their PE stories in a reflective and written manner. Teacher candidates' use of reflective journaling practices offered the potential for perceptual and conceptual change through critical reflection - leading to enhanced understandings of their own practical theory and a more complete view of the relationship that exists between what $\mathrm{PE}$ teachers do in practice and the personal reasons that underpin PE pedagogical decisions (Sanders \& McCutcheon, 1986).

\section{HONOURING ABORIGINAL WORLDVIEWS}

The "teacher candidates" in this study were a cohort of nine Aboriginal elementary educators enrolled in a PE pedagogy course offered under the auspices of an Aboriginal Teacher Education Program at one southern Ontario university. Teacher candidates are all working paraprofessional educators in remote northern Ontario community schools and, as such, all bring a wealth of experience and expertise to their health and PE teacher education. Inspired by the work of Swanson (2003) and Toulouse (2008), pedagogical experiences were designed and guided by the following tenets: 
1. Honour and respect teacher candidates' lived experience, cultural background, and unique community reality.

2. Endeavour to meet teacher candidates' wholistic needs (spiritual, physical, emotional, and intellectual) through experiential, kinesthetic, visual, and reflective teaching methods.

3. Together with teacher candidates, create a safe and welcoming environment - one that fosters and celebrates joy in learning, fun, laughter, and shared experiences.

The instructor was particularly sensitive to co-establishing a learning environment that was respectful of teacher candidates' socio-cultural and epistemic traditions. In this way, no formal lectures were delivered. Instead, informal discussions between and with students and the instructor were in circles and consisted of voluntary storytelling between participants relating to, for example, dance forms and daily physical activities in the context of their teaching practices. The learning environment was purposefully co-established in this manner to be respectful of participants' contemporary and traditional knowledge and learning (Robinson, Barrett, \& Robinson 2016; Trudeau \& Cherubini, 2010). Moreover, the design and delivery of the course facilitated opportunities for the teacher candidates and instructor to learn from and about Aboriginal sociolinguistic and traditional worldviews (see, for example, Kovach, 2005). Given the uniqueness of these worldviews, the emphasis was on the social process of learning in the spirit of healthy and sustaining relationships (Battiste \& McLean, 2005). The intent was to respect the teacher candidates' identities as Aboriginal peoples, learners, and paraprofessionals in a wholistic learning environment that honoured their mind, bodies, and spirits (Cajete, 2008).

\section{REFLECTIVE JOURNALING IN TEACHER EDUCATION}

Reflective practices in teacher education are widely accepted as fundamental components of teacher candidates' emerging pedagogy (Brookfield, 1995; Harford \& MacRuairc, 2008; Zeichner \& Liston, 1987). Reflective journaling, a methodological approach widely utilized to promote reflective practice, may assist teacher candidates to reflect upon and enhance teaching practice (Labelle \& Belknap, 2016). Hubbs and Brand (2005) have noted that "the rationale for using reflective journaling in higher education is grounded in general learning theory, adult learning theory, experiential learning theory, and in the importance of...personal growth and professional development" (p. 61). Reflective journaling, as a method of inquiry, was introduced as a compulsory course component. Its use was positioned as a place for teacher candidates to: (a) consolidate their thoughts derived out of course-based PE experiences, (b) engage in personal discussions with the instructor regarding their expectations, understandings, and challenges associated with their PE teaching experiences within their own communities, and (c) help them ex- 
plore the impacts of their own PE student experiences on their PE practical theory. Reflective journaling practices provided the study participants with an opportunity to critically analyze prior experiences in order to make explicit their own traditional views of PE teaching and learning acquired through their paraprofessional experiences, teacher training, and school experiences as students. A sample of some of the topics discussed within the course included assessment practices, land-based PA, culturally relevant PE, provincial PE curricula, explorations of Aboriginal and Western views of healthy living, learning theories and instructional models, new teachers' practical experiences, problem-based learning PE activities, influence of personal biography on PE instruction, and development of community-based cultural approaches and considerations for PE teachers.

\section{RESEARCH METHODS}

The research methodology was designed to explore, alongside Aboriginal teacher candidates, emerging PE practical theory. The process of exploring Aboriginal teacher candidates' PE practical theory was accomplished as an interpretive task employing reflective journaling and its related techniques as the research framework (outlined later in this section). Additionally, anecdotal notes collected from open conversations and class discussions were analyzed in collaboration with participants (Chilisa, 2012; Wilson, 2008). As Euro-Canadian scholars, we entered into our explorations, alongside teacher candidates, acknowledging and respecting Aboriginal ways of being, knowing, and doing (Kitchen, Cherubini, Trudeau, \& Hodson, 2009; Orr, Robinson, Lunney Borden, \& Tinkham, 2017; Robinson, Barrett et al., 2016; Robinson, Lunney Borden et al., 2012; Wilson, 2008). Careful attention was paid to ensure that the study design and implementation were culturally sensitive - rooted in honesty, respect, and care for the teacher candidates.

\section{Research ethics and consent}

Ethical approval, in accordance with the researchers' university Research Ethics Board and the university's Aboriginal Research Advisory Circle were sought and granted. All nine teacher candidates offered their written consent. Steps were taken to ensure teacher candidates' confidentiality and anonymity in the reporting and we are most thankful to the participants for consenting to share their written reflections of PE knowledge, experience, and values.

\section{Participants}

As previously noted, the "teacher candidates" were a cohort of nine Aboriginal educators enrolled in a PE pedagogy course offered under the auspices of an Aboriginal Teacher Education Program at one southern Ontario university. Eight of the nine participants self-identified as female. All of the participants were working paraprofessional educators in schools from distinct and unique remote First Nations communities in central Canada. 


\section{Reflective journaling procedures}

Teacher candidates were introduced to reflective journaling, a compulsory component of a PE teaching methods course, during the second session of the course. Teacher candidates were provided with a reflective journaling guideline outlining the purpose and structure of their journaling efforts. Reflective journaling was positioned as a method for teacher candidates to: (a) make sense of their experiences within a PE methods course, (b) converse with the instructor regarding their paraprofessional PE teaching experiences, and (c) consider how their own experiences in PE, as students, influence their $\mathrm{PE}$ teaching practices.

Teacher candidates were asked to respond to a specific set of questions, case scenarios, topics, and comments that emerged in our shared course experiences throughout the duration of the course. A block of dedicated reflective writing time, 15-20 minutes, was provided at the conclusion of each class. In an effort to honour and respect the personal nature of the reflective communications, the instructor would respond, privately, with feedback, comments, or non-threatening reflective questions that served as a way to help the teacher candidates further explore a thought, feeling, reaction, or reflection (Francis, 1995). Journal entries and personal dialogues between teacher candidates and instructor were kept private and confidential unless a teacher candidate clearly indicated that he or she was interested and comfortable with the idea of discussing shared thoughts openly with colleagues. This occurred more frequently as we progressed into the latter stages of the course offering.

\section{Data analysis}

Data from journals and anecdotal notes were analyzed in collaboration with the participants (Chilisa, 2012; Wilson, 2008). Thematic analysis (Bernard \& Ryan, 1998; Boyatzis, 1998) was employed to analyze the data. Each reflective journal was considered as a textual whole and was initially examined as an independent text. From the written narratives, key phrases, and words in each of the responses were confirmed in researcher / teacher candidate dialogue and then recorded. Responses were grouped into themes. Patterns and codes between themes were factored (Patton, 1990). Descriptors were utilized and confirmed to make clear the specific properties of each theme. Throughout the analysis, care, and attention were given to ensure that researchers honoured both the unique context and diverse voices of the Aboriginal participants (Kovach, 2010). Patterns were grounded in the voices of the participants. It was our intent to be mindful of the intercultural dynamics at play in our analyses - we sought not to juxtapose the patterns with predetermined theories; instead, forward and backward movement in the data analyses coupled with confirmation and dialogue with participants served to underpin and refine our emergent themes (Cherubini \& Barrett, 2014). 


\section{FINDINGS}

The four themes that emerged through the analysis of teacher candidates' reflective journals provided insights into Aboriginal teacher candidates' emerging PE practical theory, and included: (a) Marginality (foreign activities and stereotypical expectations), (b) Cultural preservation through PE, (c) Elder involvement in PE, and (d) Looking to the future.

\section{Marginality (foreign activities and stereotypical expectations)}

In a number of passages, participants described aspects of their PE experiences from a student perspective. All, at one time or another in their journey through K-12 education, described their participation in PE activities that were either foreign and/or PE activities that lacked any relevance to their worldviews as First Nations peoples. Further, participation in foreign activities were often accompanied by stereotypical expectations. Both non-aboriginal students and Euro-Canadian teachers often made assumptions about specific sport and physical activity competency and knowledge derived out of, what would appear to be, stereotypical understandings of Aboriginal traditions. As such, little was done to support their introduction into new activity experiences in PE. Sally recalled a particular unfounded expectation based on her experience as a secondary school student: "I wasn't too good in archery...the other students and teacher thought I would do great because I was native... bows and arrows I guess... I had never used a bow or arrow in my life."

Jane shared an example that was typical of other participants' comments:

Some of the things that were taught to us were foreign...we had never heard of them before. I remember one teacher introduced the activity [and then] told us later, "You students all had blank looks on your faces." We were expected to keep playing even though we didn't know anything.

Finally, Marcy shared:

When I was a student, my gym experiences weren't that great. I was so shy / scared to participate in the activities but the teacher pushed me into them. Where I lived, we had never played activities such as soccer and baseball.

Results suggest teacher candidates' emerging PE practical theories were significantly influenced by early PE experiences characterized, in part, by feelings of marginality and participation in activities that lacked cultural relevance. Equally concerning, and consistent in their reflections, were descriptions of PE experiences delivered by teachers who lacked a connection to their Aboriginal students. As noted by Halas, McRae, and Petherick (2012),

while most of today's teachers were not involved or present during the residential school era, the legacy of distrust that remains between some Aboriginal families and the school systems is worth considering - teachers who take time to get to know an individual student's situation, interests, challenges, and ambitions will be better positioned to motivate the student to be actively engaged in class. (p. 8) 


\section{Cultural preservation through PE}

Many of the participants' PE practical theories were rooted in a value system orientation that sought to improve the lives of Aboriginal children through the provision of culturally relevant PE opportunities - a potential way of preserving culture, language, and tradition. Jennifer, in particular, wrote about her desire to see land-based cultural physical activities figure more prominently in $\mathrm{PE}$ programming as a way to engage Aboriginal children in traditional, linguistic, and cultural teachings:

Our children enjoy learning about and playing the games that the elders teach them...our children will often want to play these games in PE...it seems that our culture and language are fading fast...many of the students coming into junior kindergarten (JK) have English as their first language. Why not include our games? Our ways...food preparation, hunting, trapping, fishing?

This idea also resonated with Janice. She proposed the inclusion of physical activities that were rooted in First Nations' rich cultural heritage:

There were many traditions that were lost that kept us healthy and happy before contact. They must have done something right. Instead of the program always being one-sided [all English], I would like to see us bring our culture and language into PE with activities, games, and such.

These findings are consistent with the notions put forth by Robinson, Lunney Borden et al. (2012), who noted that "currently, throughout all of Canada, Aboriginal students are routinely introduced to curricula and/or pedagogies that are plainly incongruous or discordant with both their contemporary and historical ways of knowing" (p. 527). The lack of culturally relevant PE opportunities for Aboriginal children is of concern to the participants and, as such, had influenced their PE practical theory. Consistent across teacher candidates' reflections, and as they progressed through the course, it became clear that participants were viewing their role as Aboriginal teachers of PE in a different way. They viewed Aboriginal PE teachers and PE teaching as playing key roles in the preservation of valued linguistic and historical traditions through the purposeful inclusion of culturally relevant physical activities.

\section{Elder involvement in PE}

Linked to the preservation of culture was an overwhelming desire to tap into the cultural capacity and knowledge present in community Elders. All of the participants' reflections strongly situated community Elders as playing a vital role in the shaping of their emerging PE practical theories. Related to PE teaching, many suggested that Elders should figure more prominently in PE-related decision-making - achieved through the infusion of Aboriginal worldviews and traditional knowledge in PE teacher preparation, professional development, and daily PE instruction. Consistent across participants' reflections was the 
heightened concern over the increasing number of Elders passing on and the resultant loss of invaluable traditional knowledge and teaching particular to a community (Cherubini \& Barrett, 2014). Kim wrote about the important influence the Elders had on students from her community and expressed concerns over the loss of Elders:

In the past, when they [students] were taught traditional games by our Elders, they used to find it fascinating. Our Elders used to have input on what should be taught in schools not only in PE but in all areas...our schools need to find a way to preserve our land-based teachings. This year, I think four or five Elders passed away...this never happened before.

Sally reflected upon her role as a Grade 5 teacher working alongside an Elder from her community:

My education assistant who is also our Elder works with me. She has given me many ideas on what I can include in my PE activities. She has been at the school for a long time. Other teachers I work with say they miss the input of the Elders. Some of the middle generation often comment how they don't see the activities done in our school like they were done in the past. It's sad and we need to do more to involve our Elders in our teaching of PE.

These findings affirm the well-understood and essential role that Aboriginal Elders play in the transferring of linguistic, cultural, and traditional knowledge within First Nations communities (Cherubini \& Barrett, 2014; Elijah, 2002; Fishman, 2001).

\section{Looking to the future}

Finally, reflective journaling exercises embedded within a PE teaching methods course inevitably led teacher candidates to consider the impact of their own practical theories and learning on their future practice as teachers of PE. Thinking about his own future, John reflected upon his own ancestors' journey:

Long ago our people were very active. They walked long ways to get to their traditional lands for the winter seasons and traveled back many miles in the spring to the gathering area...I will remind our students of this and I will help teach our people how to live healthier lifestyles.

Sue considered the potential relationship and impact of role modeling healthy behaviours on her own students participating in PE:

My health is important too. My students need to see that PE is important to me too. I will be trying to participate in the games and activities with my students. I want them to see me being healthy and enjoying our activities.

Jennifer was particularly motivated to be a better PE teacher as a result of her less than ideal experiences in PE as a student: 
I hope my teaching of PE will have a positive impact on my kids and my students. I didn't have the best PE teachers in my reserve school and I want my kids and my students to have a better experience than I did. I want them to be active and I want them to have fun.

\section{DISCUSSION}

This research attended to Aboriginal teacher candidates, working as paraprofessional educators in northern Canadian First Nations communities, and their exploration of their emerging PE practical theory. The study utilized reflective journaling practices within a PE teaching methods course. This approach honoured the knowledge of the Aboriginal participants through introspection and self-reflection (Battiste 2002) and attempted to help teacher candidates' surface and make explicit the knowledge, lived experiences, and core values that make up and influence their emerging PE pedagogy (Handal \& Lauvas, 1987; Zeichner \& Liston, 2014). The analysis and confirmation of participants' reflective writing and follow-up dialogue yielded four themes that offered glimpses into experiences and core values that have helped shape Aboriginal teacher candidates' emerging PE practical theories.

These Aboriginal teacher candidates' stories of marginalization in K-12 physical education deserve purposeful and focused attention. Such attention might necessarily require action upon two fronts. First, it is important to address these (and other current / future) Aboriginal teacher candidates' experiences in K-12 physical education, head-on. That is, despite their education in a postresidential school era, the absence of cultural congruence with their own PE experiences suggests that they were participants in a system that continued to colonize those with opposing worldviews. Addressing these experiences means educating them about curricular and pedagogical possibilities that were, unfortunately, missed in their own K-12 years. Such education will require and enable them to see how their own ways of being, and moving, might also be viewed as possible core elements of PE programs. They deserve to hear about how the system failed. Second, while addressing this systemic failure provides one response to the situation, clearly, we also need a path towards a better future. This better future is one in which commitments to ensure the development of culturally appropriate curricula for all First Nations peoples are realized (Truth and Reconciliation Commission of Canada, 2015).

Within PE, this may begin to occur once Aboriginal PE teachers (and all other PE teachers) recognize the need for, and enact, culturally relevant PE for Aboriginal students. This, of course, is not an easy nor quick task. It will take many people and many generations to make this possible. Still, PE curriculum and instruction needs to be more clearly reflective of distinct First Nations' circumstances, taking into account their unique language, cultural values and beliefs, and local necessities. The research findings underscore the significance of PE teachers, both Aboriginal and non-Aboriginal, to foster effective and 
culturally respectful pedagogical practices that not only reflect favourably upon Aboriginal students' learning interests, but honour the sophisticated series of beliefs and traditions that inform Aboriginal epistemologies (Pidgeon, Munoz, Kirkness, \& Archibald, 2013). Teachers are, thus, commissioned to represent Aboriginal students' worldviews and learning needs in the social and cultural fabric of their classrooms (Cherubini, 2016). This research points to the importance of prospective teachers' self-interrogation into their understandings and assumptions of what it means to teach and learn. Reflection is necessary for the successful implementation of the aforementioned pedagogical reforms. Such reforms, we acknowledge, will be gradual. However, the key findings of this study raise hope and generate support for the fact that Aboriginal student voices need to be represented in the pedagogy of K-12 school classrooms in order for Aboriginal cultures to deeply inform student (and teacher) learning.

Moreover, the study calls upon Elders (as traditional knowledge-keepers) to help shape the discourse of teachers' pedagogy in K-12 schools. Moving forward in the context of transforming current practice implies that teachers, principals, and school-board leaders more broadly construe and then espouse the notion of collaborating with the Elders of the respective school communities to complement the Eurocentric curriculum and teachers' Western-based pedagogy with culturally-respectful and sensitive perspectives. In this way, schools and classrooms can be powerful learning environments that address the academic development and potential of Aboriginal and non-Aboriginal students alike. Evidence gleaned from this study may also serve as a reminder to PETE faculty and, more broadly, teacher education programs, that they have a moral obligation to answer the Truth and Reconciliation Commission of Canada's (2015) call for post-secondary institutional allocation of the necessary resources to educate teachers on how to integrate Aboriginal knowledge and teaching methods in classrooms. Similar sentiments were echoed in the work of Robinson et al. (2012):

Immediate and meaningful education related to cultural responsiveness needs to be an integral part of physical education teacher education programs. Such education cannot occur through coursework alone (and it certainly cannot be accomplished through a single stand-alone 3-credit course). Pre-service teachers need authentic opportunities to engage with Aboriginal students and communities (i.e., through field experiences, tutoring, service learning, etc.). (p. 539)

The extent and consistency in teacher candidates' desire to see greater involvement of Elders in facets of PE education (teacher education, curriculum writing, and instruction) were aligned with Battiste's (2002) assertions that Aboriginal student successes can be found "where Aboriginal languages, heritages and communities are respected, supported, and connected to Elders and education" (p. 17). It was clear that teacher candidates' PE practical theories were built upon, in part, an underlying belief in the necessity for Elder participation in 
all decisions related to PE pedagogy. This was primarily articulated in various dialogues and reflective journals - all of which consistently reinforced their desire to have local Elders directly involved in the integration of wholistic approaches to pedagogy (Little Bear, 2009) that are grounded in Aboriginal knowledge and perspectives.

\section{CONCLUSION}

The reflective journaling methodology incorporated philosophical underpinnings that complemented the pragmatic approach employed in this study. It represented opportunities for teacher candidates to make intriguing connections between the personal stories they shared, their experiences in the classroom, and the course content. The process of reflective journaling was especially conducive to open dialogue and respectful deliberation during the course. Teacher candidates were candid in the expression of the underlying values that governed their teaching choices and paraprofessional behaviours in their respective schools. Further, their reflections underscored the significance of the traditional and contextual variables as they relate to PE, including the centrality of Elders as traditional knowledge-keepers for both current and future teachers and learners.

\section{REFERENCES}

Battiste, M. (2002). Indigenous knowledge and pedagogy in First Nations education: A literature review with recommendations. Prepared for the National Working Group on Education and the Minister of Indian Affairs. Ottawa, ON: Indian and Northern Affairs Canada (INAC).

Battiste, M., \& McLean, S. (2005). State of First Nations learning. Prepared for the Canadian Council on Learning. Saskatoon, SK: Aboriginal Education Research Centre.

Bernard, H. R., \& Ryan, G. W. (1998). Qualitative and quantitative methods of text analysis. In H. R. Bernard (Ed.), Handbook of research methods in cultural anthropology (pp. 595-646). Walnut Creek, CA: AltaMira.

Boyatzis, R. E. (1998). Transforming qualitative information: Thematic analysis and code development. Thousand Oaks, CA: Sage.

Brookfield, S. D. (1995). Becoming a critically reflective teacher. San Francisco, CA: Jossey-Bass.

Cajete, G. (2008). Sites of strength in Indigenous research. In M. Villegas, S. R. Rak Neugebauer, \& K. R. Venegas (Eds.), Indigenous knowledge and education (pp. 204-210). Cambridge, MA: Harvard Educational Press.

Champagne, L. (2006). Physical education teachers as allies to aboriginal students: Dimensions of social consciousness (Unpublished master's thesis). University of Manitoba, Winnipeg, MB.

Cherubini, L. (2016). The Ontario (Canada) Ministry of Education's A Solid Foundation document: An extended commentary. British Journal of Education, 14(3), 1-10.

Cherubini, L., \& Barrett, J. M. (2014). Teaching and learning in remote northern Ontario schools: Aboriginal teacher perceptions. Native Studies Review, 22(1-2), 157-170.

Chilisa, B. (2012). Indigenous research methodologies. Thousand Oaks, CA: Sage.

Dewey, J. (1938). Experience and education. New York, NY: Macmillan. 
Dorovolomo, J. (2004). Teachers' practical theory: Personal articulation and implications for teachers and teacher education in the Pacific. Pacific Curriculum Network, 13(1-2), 10-16.

Elijah, M. J. (2002). Literature review: Language and culture. Prepared for the Minister's National Working Group on Education. Ottawa, ON: Author.

Fishman, J. (2001). Why is it so hard to save a threatened language? In J. Fishman (Ed.), Can threatened languages be saved? (pp. 1-22). Toronto, ON: Multilingual Matters.

Francis, D. (1995). The reflective journal: A window to preservice teachers' practical knowledge. Teaching and Teacher Education, 11(3), 229-241.

Gillis, A. (2001). Journal writing in health education. New Directions for Adult and Continuing Education, 90, 49-58.

Halas, J., McRae, H., \& Petherick, L. (2012). Advice for physical education teachers from Aboriginal youth: Become an ally. Physical $\mathcal{B}$ Health Education Journal, 78(3), 6-11.

Handal, G., \& Lauvas, P. (1987). Promoting reflective teaching: Supervision in action. Milton Keynes, UK: Open University Press.

Harford, J., \& MacRuairc, G. (2008). Engaging student teachers in meaningful reflective practice. Teaching and Teacher Education, 24(7), 1884-1892.

Hubbs, D. L., \& Brand, C. F. (2005). The paper mirror: Understanding reflective journaling. The Journal of Experiential Education, 28(1), 60-71.

Kitchen, J., Cherubini, L., Trudeau, L., \& Hodson, J. (2009). Aboriginal education as cultural brokerage: New aboriginal teachers reflect on language and culture in the classroom. McGill Journal of Education, 44(3), 355-375.

Kovach, M. (2005). Emerging from the margins: Indigenous methodologies. In L. Brown \& S. Strega (Eds.), Research as resistance (pp. 19-36). Toronto, ON: Canadian Scholars' Press.

Kovach, M. (2010). Conversational method in Indigenous research. First Peoples Child $\mathfrak{E}$ Family Review, 5(1), 40-48.

Labelle, J. T., \& Belknap, G. (2016). Reflective journaling: Fostering dispositional development in preservice teachers. Reflective Practice, 17(2), 125-142.

Little Bear, L., (2009). Naturalizing Indigenous Knowledge [Synthesis paper]. Retrieved from http:// www.afn.ca/uploads/files/education/21. 2009 july ccl-alkc leroy littlebear naturalizing indigenous knowledge-report.pdf

Lortie, D. C. (1975). Schoolteacher. Chicago, IL: University of Chicago Press.

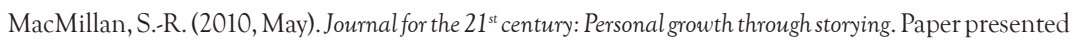
at the Language and Literacy Graduate Student Conference. University of Victoria, Victoria, BC.

Matanin, M., \& Collier, C. (2003). Longitudinal analysis of preservice teachers' beliefs about teaching physical education. Journal of Teaching in Physical Education, 22(2), 153-168.

McNeil,J. D. (1996). Curriculum: A comprehensive introduction (5 $5^{\text {th }}$ ed.). Toronto, ON: John Wiley \& Sons.

Morgan, P., Bourke, S., \& Thompson, K. (2001, December). The influence of personal school physical education experiences on non-specialist teachers' attitudes and beliefs about physicaleducation. Paper presented at the meeting of the Australian Association for Research in Education, Freemantle, Australia.

Morgan P., \& Hansen, V. (2008). The relationship between PE biographies and PE teaching practices of classroom teachers. Sport Education and Society, 13(6), 373-391.

Orr, J., Robinson, D. B., Lunney Borden, L., \& Tinkham, J. (2017). “There is a difference”: Mi’kmaw students' perceptions and experiences in a public school and in a band-operated school. Journal of American Indian Education, 56(1), 55-80.

Patton, M. Q. (1990). Qualitative evaluation and research methods (2 $2^{\text {nd }} \mathrm{ed}$.). Thousand Oaks, CA: Sage.

Pidgeon, M., Munoz, M., Kirkness, V. J., \& Archibald, J. (2013). Indian control of Indian education: Reflections and envisioning the next 40 years. Canadian Journal of Native Education, 36(1), 5-35. 
Placek, J. H., Dodds, P., Doolittle, S. A., Portman, P. A., Ratliffe, T. A., \& Pinkham, K. M. (1995). Teaching recruits' physical education backgrounds and beliefs about purposes for their subject matter. Journal of Teaching in Physical Education, 14(3), 246-261.

Portman, P. (1996). Preservice elementary education majors' beliefs about their elementary physical education classes (Part 1). Indiana Association for Health, Physical Education, Recreation and Dance Journal, 25(2), 25-28.

Robinson, D. B., Barrett, J. M., \& Robinson, I. M. (2016). Culturally relevant physical education: Educative conversations with Mi'kmaw Elders and community leaders. in education, 22(1), 2-21.

Robinson, D. B., Lunney Borden, L., \& Robinson, I. M. (2012). Charting a course for culturally responsive physical education. Alberta Journal of Educational Research, 58(4), 526-546.

Sanders, D., \& McCutcheon, G. (1986). The development of practical theories of teaching. Journal of Curriculum and Supervision, 2(1), 50-67.

Swanson, S. (2003). Motivating learners in northern communities. Canadian Journal of Native Education, 27(1), 16-25.

Toulouse, P. R. (2008, March). Integrating aboriginal teaching and values into the classroom. What Works? Research into Practice\# 11. Retrieved from http://www.edu.gov.on.ca/eng/literacynumeracy/inspire/ research/Toulouse.pdf

Trudeau, L., \& Cherubini, L. (2010). Speaking our truths in a "good way." Canadian Journal of Native Education, 33(1), 113-121.

Truth and Reconciliation Commission of Canada (2015). Calls to Action. Retrieved from http:// www.trc.ca/websites/trcinstitution/File/2015/Findings/Calls to Action English2.pdf

Wilcox, R. (1987). The failing of high school physical education. Journal of Physical Education, Recreation $\mathcal{E}$ Dance, 58(6), 21-25.

Wilson, S. (2008). Research is ceremony: Indigenous research methods. Halifax, NS: Fernwood.

Zeichner, K. M., \& Liston, D. P. (1987). Teaching student teachers to reflect. Harvard Educational Review, 37, 23-49.

Zeichner, K. M., \& Liston, D. P. (2014). Reflective teaching: An introduction (2 ${ }^{\text {nd }}$ ed.). New York, NY: Routledge.

JOE BARRETT is an associate professor in the Faculty of Education at Brock University (St. Catharines, Ontario, Canada). His research is oriented around the following areas: (a) school health policy, (b) physical and health education teacher education (PHETE), (c) culturally relevant physical and health education pedagogy, and (d) sport coaching pedagogy.jbarrett@brocku.ca

LORENZO CHERUBINI is a professor in the Faculty of Education at Brock University (St. Catharines, Ontario, Canada). His research is concentrated primarily in the areas of teacher development, English Education and policy analysis. Icherubini@brocku.ca

DAN ROBINSON is chair of Teacher Education and an associate professor at St. Francis Xavier University (Antigonish, Nova Scotia, Canada). His current scholarship focuses upon physical literacy, physical education teacher education (PETE), experiential and service learning, social justice, and culturally relevant physical education pedagogy. drobinso@stfx.ca 
JOE BARRETT est professeur à la faculté d'éducation de Brock University (St. Catharines, Ontario). Ses recherches sont orientées autour des domaines suivants : (a) la politique de santé à l'école, (b) la formation des enseignants à l'éducation physique et sanitaire (FEEPS), (c) une pédagogie de l'éducation physique et sanitaire culturellement pertinente et (d) la pédagogie du coaching sportif. jbarrett@brocku.ca

LORENZO CHERUBINI est professeur à la faculté d'éducation de Brock University (St. Catharines, Ontario,). Ses recherches se concentrent principalement dans les domaines du perfectionnement des enseignants, de l'éducation en anglais et de l'analyse des politiques. Icherubini@brocku.ca

DAN ROBINSON est responsable de la formation initiale et est un professeur à St. Francis Xavier University (Antigonish, Nouvelle-Écosse). Ses recherches actuelles portent sur la culture physique, la formation des enseignants d'éducation physique, l'apprentissage par l'expérience et le service, la justice sociale et une pédagogie de l'éducation physique pertinente sur le plan culturel. drobinso@stfx.ca 